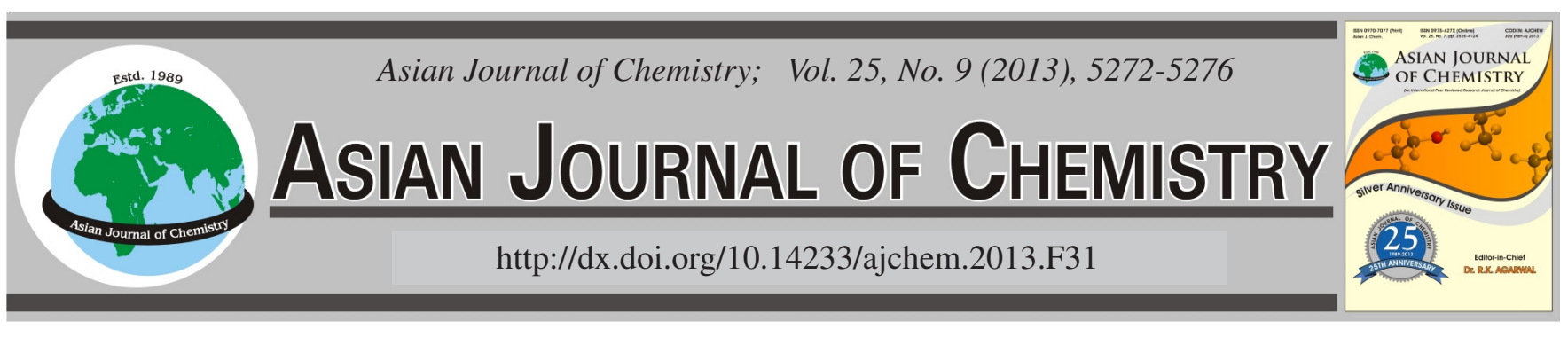

\title{
Mechanical Properties and Recyclability of Ionic Thermoplastic Rubber Based on Citraconated Ethylene Propylene Diene Monomer $\dagger$
}

\author{
J.W. BAE ${ }^{1}$, J.S. KIM ${ }^{1}$, J.H. LEE ${ }^{1}$, G.N. KIM ${ }^{1}$, S.T. OH ${ }^{1}$, Y.H. LEE ${ }^{2}$ and H.D. KIM ${ }^{2, *}$
}

${ }^{1}$ Industrial Materials Fusion Technology Center, Korea Institute of Footwear and Leather Technology, Busan 614-100, Republic of Korea ${ }^{2}$ Department of Organic Material Science and Engineering, Pusan National University, Busan 609-735, Republic of Korea

*Corresponding author: Fax: +82 51 5128175; Tel: +82 51 5102410; E-mail: kimhd@ pusan.ac.kr

\begin{abstract}
The mechanical properties and recyclability of novel ionomers based on citraconated ethylene propylene diene monomer (EPDM) were examined. Citraconated EPDM (CCA-g-EPDM) was synthesized using a melt grafting technique from citraconic acid (CCA)/EPDM/free radical initiator [2,5-dimethyl-2,5-di(tert-butyl peroxy) hexane: L-101]. Ionomers $\left(\mathrm{I}_{\mathrm{ZnO}(5)}, \mathrm{I}_{\mathrm{ZnO}(10)}, \mathrm{I}_{\mathrm{ZnSt.}(5)}, \mathrm{I}_{\mathrm{ZnSt} .(10)}, \mathrm{I}_{\mathrm{ZnO}(5) / \mathrm{ZnSt} .(5))}\right.$ based on citraconated EPDM were prepared by melt mixing from CCA-g-EPDM and zinc oxide and/or zinc stearate using a Haake Rheocorder. This study compared the mechanical properties of pristine EPDM, CCA-g-EPDM and pristine/recycled ionomers. The density, tensile strength, elongation at break, modulus and tear strength increased in the order, ionomers > CCA-g-EPDM > pristine EPDM, whereas the

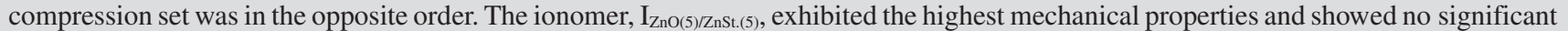
change in the mechanical properties and compression set with successive recycling. These results suggest that the recyclable ionomers based on citraconated EPDM prepared in this study have high potential as new high performance thermoplastic elastomers.
\end{abstract}

Key Words: Ionic thermoplastic rubber, Citraconated ethylene propylene diene monomer, Mechanical properties, Recyclability.

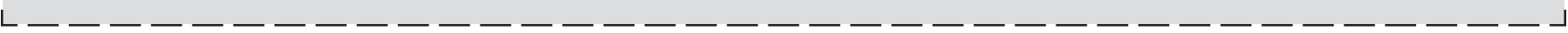

\section{INTRODUCTION}

Generally, the crosslinking of elastic materials is necessary to obtain the required rubber properties, such as high elasticity, high toughness and good solvent resistance. On the other hand, the main industrial technologies for rubber crosslinking, i.e. sulfur vulcanization and peroxide curing, involve irreversible covalent crosslinking, which prevents melt processing and strongly complicates recycling ${ }^{1}$. An attractive solution to overcome the recycling problem is to use elastomers exhibiting thermoplastic behaviour, so-called thermoplastic elastomers. Thermoplastic elastomers are materials that, in the ideal case, combine the service properties of crosslinked elastomers with the melt processing properties of thermoplastics. Most commercial thermoplastic elastomers are block copolymers consisting of hard and soft segments like thermoplastic polyurethane.

The introduction of a small number of ionic groups into the polymer chains with acid/base groups can result in profound changes in the properties of modified polymers, also known as ionomers ${ }^{2-4}$. Ionomers are another class of material with thermoreversible crosslinks. These are polymers that contain a relatively small fraction of ionic groups, either pendant to or incorporated in the polar main chain. Depending on the concentration of these ionic groups, the ionic aggregates can exist as multiplets, which function as physical crosslinks, or as clusters, consisting of the ion pairs and hydrocarbon chains, often leading to microphase separation ${ }^{5-8}$. The reversibility of the ionic crosslinks is based on the increased mobility of the ionic aggregates at elevated temperatures. Therefore, ionomer-based on polymers with a low $\mathrm{T}_{\mathrm{g}}$ can be used as thermoplastic elastomers, if the ionic associations are sufficiently weakened at the processing temperature ${ }^{9-11}$. The ionic crosslinks are thermolabile and the materials can be processed like thermoplastics.

Large amounts of scrap arise at the end of the servicetime of thermoplastic polymer articles. Therefore, the question of the disposal of used polymer has gained increasing importance in public discussions because of the environment problems resulting from the rapid increase in plastic wastes. In general, melt recycled polymers exhibit unsatisfactory mechanical properties because of their degradation during reprocessing. The reproducing involves several high temperature shearing cycles that facilitate (i) the occurrence of thermal and/or mechanical degradation, (ii) consequent chemical and physical changes and (iii) a deterioration of the final properties. 
Therefore, an in-depth understanding of the influence of melt processing/recycling on the properties of thermoplastics is essential for effective mechanical recycling of used thermoplastics and thermoplastics scraps.

Ionomers with different cations, namely zinc, potassium, sodium and copper are obtained via the neutralization of a polymer containing acid groups with metal compounds for different degrees of neutralization ${ }^{2,12-15}$. Ionic rubbers are mostly prepared by the metal ion neutralization of acid functionalized rubbers, such as carboxylated styrenebutadiene rubber and carboxylated nitrile rubber ${ }^{13,16-18}$. Ionic rubbers under ambient conditions exhibit moderate to high tensile and tear strength and high elongation. Ethylene propylene diene monomer (EPDM) rubber functionalized by sulfonation, maleation and citraconation form sulfonated, maleated and citraconated ethylene propylene diene monomer, respectively. Ionic rubbers based on sulfonated ethylene propylene diene monomer rubber ${ }^{19-21}$ and maleated ethylene propylene diene monomer ${ }^{22-24}$ have been studied by several workers. However, ionic rubber based on citraconated ethylene propylene diene monomer has not been studied as a potential ionomer. Therefore, understanding the effect of melt processing/ recycling on the properties of citraconated ethylene propylene diene monomer-based ionomers is very important for reusing. On the other hand there is a paucity of reports related to citraconated ethylene propylene diene monomer-based ionomers.

In the present study, citraconic acid-g-ethylene propylene diene monomer was prepared from citraconic acid (CCA), ethylene propylene diene monomer and free radical initiator [2,5-dimethyl-2,5-di(tert-butyl peroxy) hexane: L-101] using a melt grafting technique with a Haake Rheocorder 9000. Ionomers based on citraconated ethylene propylene diene monomer were also prepared by melt mixing from CCA-gEPDM and zinc oxide and/or zinc stearate. The mechanical properties of the pristine ethylene propylene diene monomer, CCA-g-EPDM, pristine citraconated ethylene propylene diene monomer-based ionomer and recycled (up to 4 times) citraconated ethylene propylene diene monomer-based ionomers were compared. The effect of the $\mathrm{ZnO}$ and/or zinc stearate content on the mechanical properties was also investigated.

\section{EXPERIMENTAL}

Ethylene propylene diene monomer (contents of ethylene, propylene and ethylidenenorbornen: 70, 25.5 and $4.5 \mathrm{wt} \%$, respectively, KUMHO POLYCHEM, Korea), citraconic acid (CCA, Aldrich Chemical, Milwaukee, WI), 2,5-dimethyl-2,5di(tert-butyl peroxy)-hexane(L-101, Akzo Novel Co. Ltd., USA), Zinc oxide ( $\mathrm{ZnO}$, PJ Chemtec Co. Ltd., Korea), zinc stearate(Zn St., Aldrich Chemical, Milwaukee, WI), toluene (Junsei Chemical Co. Ltd.), acetone (Junsei Chemical Co. Ltd.) were used without further purification.

Citraconated ethylene propylene diene monomer (CCAg-EPDM) was prepared from citraconic acid (CCA)/EPDM/ free radical initiator [2,5-dimethyl-2,5-di(tert-butyl peroxy) hexane: L-101] using a melt grafting technique with a Haake Rheocorder (Rheocord 9000, Haake Co. Germany) at $50 \mathrm{rpm}$ and $160^{\circ} \mathrm{C}$ for $15 \mathrm{~min}$. Ionomers based on citraconated ethylene propylene diene monomer were prepared by melt mixing from CCA-g-EPDM and zinc oxide and/or zinc stearate using a Haake Rheocorder under $50 \mathrm{rpm}$, at $160^{\circ} \mathrm{C}$ for $15 \mathrm{~min}$. Sheet samples (thickness: $2 \mathrm{~mm}$ ) of pristine ethylene propylene diene monomer, CAA-g-EPDM and ionomers were prepared by milling using an open mill (Yasuda Seiki Co. Model 191-TM, 6) at $160-170{ }^{\circ} \mathrm{C}$, followed by compression- molding at $180{ }^{\circ} \mathrm{C}$ for $10 \mathrm{~min}$.

Detection method: Attenuated total reflectance (ATR)Fourier transform infrared (FTIR 6200, Jasco, Japan) spectroscopy was used to confirm the chemical components of the pristine ethylene propylene diene monomer, CCA-g-EPDM, ionomers (CCA-g-EPDM/ZnO, CCA-g-EPDM/zinc stearate and CCA-g-EPDM/ZnO/Zinc stearate). For each sample, 32 scans at a $4 \mathrm{~cm}^{-1}$ resolution were collected in transmittance mode and recorded in the $2000-600 \mathrm{~cm}^{-1}$ range. The stressstrain curves were measured using dumbbell shaped specimens according to ASTM D 412 using an Instron universal testing machine (UTM, Model: 3345, Instron, USA) at a crosshead speed of $500 \mathrm{~mm} / \mathrm{min}$. The tear strength was measured using the Instron UTM 3345 using a $90^{\circ}$ nick cut-crescent sample according to ASTM 624-86. The density was measured at $23^{\circ} \mathrm{C}$ using a $\mathrm{CCl}_{4}-n$-heptane density gradient column method. The melt flow index (MFI) measurement of the samples was carried out on a Melt Indexer CS127-604(CSI Ltd., USA) according to the ISO $1133: 1999$ standard, where the test temperature was set to $190{ }^{\circ} \mathrm{C}$ and the nominal load was $2.16 \mathrm{~kg}$. The hardness was measured using a shore A durometer (Asker, Kobunshi Co. Ltd., Japan) according to ASTM D-2240. The compression set (CS) was measured on cylindrical samples, $300 \mathrm{~mm}$ in diameter and approximately $10 \mathrm{~mm}$ in thickness. For the compression set measurements, the samples were compressed between two parallel plates with a linear deformation of $25 \%$ at $70{ }^{\circ} \mathrm{C}$ for $22 \mathrm{~h}$. The compression set was then determined after a 30 min relaxation time at room temperature without deformation according to ASTM D-3754. The compression set of the samples was calculated using the following equation:

$$
\text { Compression set }(\%)=\left[\left(\mathrm{t}_{0}-\mathrm{t}_{\mathrm{f}}\right) /\left(\mathrm{t}_{0}-\mathrm{t}_{\mathrm{s}}\right)\right] \times 100
$$

where $t_{0}$ is the original thickness of the sample $(1 \mathrm{~cm}), t_{\mathrm{f}}$ is the thickness of the recovered sample after compression at $70{ }^{\circ} \mathrm{C}$ for $22 \mathrm{~h}$ and cooling to room temperature for $0.5 \mathrm{~h}$ and $\mathrm{t}_{\mathrm{s}}$ is the thickness $(0.75 \mathrm{~cm})$ of the compressed sample. Measurements of each sample were repeated five times and the mean was considered to be the characteristic value.

\section{RESULTS AND DISCUSSION}

Citraconated ethylene propylene diene monomer (CCAg-EPDM) was prepared by melt grafting from citraconic acid (CCA), ethylene propylene diene monomer and the free radical initiator [2,5-dimethyl-2,5-di(tert-butyl peroxy) hexane: L-101] using a Haake Rheocorder 9000. Sample code, composition, grafting and gel content of CCA-g-EPDM are shown in Table-1. Preliminary experiments on the effect of the processing conditions and various peroxides initiators on the grafting and mechanical properties of CCA-g-EPDM revealed an increase in the mechanical properties and gel content with increasing grafting \%. A lower gel content resulted in easier melt processing. Therefore, the CCA-g-EPDM sample (low \% 
TABLE-1

SAMPLE CODE, COMPOSITION, GRAFTING AND GEL CONTENT OF CCA-g-EPDM

\begin{tabular}{ccccccc}
\hline \multirow{2}{*}{ Sample code } & \multicolumn{3}{c}{ Composition } & \multicolumn{3}{c}{ Grafting } \\
\cline { 2 - 5 } & Pristine EPDM & Monomer & Initiator & Grafting $(\%)$ & Graft efficiency $(\%)$ & \\
\hline CCA-g-EPDM & 100 & CCA(2) & L-101(0.04) & 1.78 & 89.0 & 18.0 \\
\hline CCA-g-EPDM: citraconated EPDM, CCA: citraconic acid, L-102: & 2,5 -Dimethyl-2,5-di(tert-butyl peroxy)-hexane &
\end{tabular}

TABLE-2

SAMPLE CODE, COMPOUNDING COMPONENTS AND PROPERTIES OF PRISTINE EPDM, CCA-g-EPDM, CCA-g-EPDM/ZnO, CCA-g-EPDM/ZINC STEARATE AND CCA-g-EPDM/ZnO/ZINC STEARATE

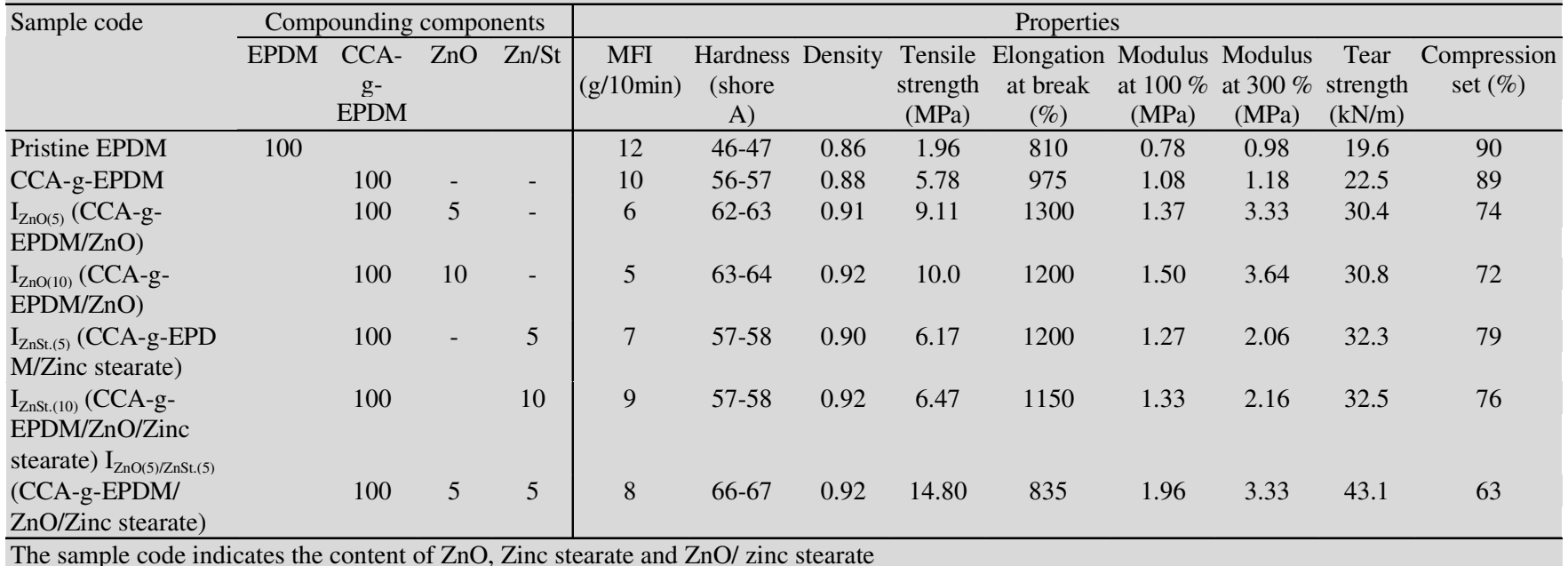

grafting: $1.78 \%$ and low gel content: $18 \%$ ) was used as a based material for the ionomers in this study.

Table- 2 shows the effect of the compounding components on the mechanical properties of the ionomers $\left(\mathrm{I}_{\mathrm{ZnO}(5)}, \mathrm{I}_{\mathrm{ZnO}(10)}, \mathrm{I}_{\mathrm{ZnSt} .(5)}\right.$, $\left.\mathrm{I}_{\mathrm{ZnSt} .(10)}, \mathrm{I}_{\mathrm{ZnO}(5) / Z n S t .(5)}\right)$ based on citraconated ethylene propylene diene monomer. The number in the I samples indicates the weight (g) of $\mathrm{ZnO}$ and zinc stearate ( $\mathrm{ZnSt}$.) per $100 \mathrm{~g} \mathrm{CCA}-\mathrm{g}-\mathrm{EPDM}$. $\mathrm{ZnO}$ could function as a $\mathrm{Zn}$ ion supplier and filler, whereas $\mathrm{ZnSt}$. could perform as a $\mathrm{Zn}$ ion supplier and plasticizer.

Fig. 1 shows the FTIR spectra of pristine ethylene propylene diene monomer, CCA-g-EPDM and ionomers $\left(\mathrm{I}_{\mathrm{ZnO}(5)}, \mathrm{I}_{\mathrm{ZnO}(10)}\right.$, $\left.\mathrm{I}_{\mathrm{ZnSt} .(5)}, \mathrm{I}_{\mathrm{ZnSt.(10)}}, \mathrm{I}_{\mathrm{ZnO}(5) / Z n S t .(5)}\right)$. The EPDM-g-CCA sample had two characteristic peaks for ethylene propylene diene monomer and citraconic acid (the $\mathrm{C}=\mathrm{O}$ stretch peak at $1704 \mathrm{~cm}^{-1}, \mathrm{C}-\mathrm{O}$ stretch peak at $1270 \mathrm{~cm}^{-1}$ for the carboxylic acid group of citraconic acid component), indicating the presence of citraconic acid in ethylene propylene diene monomer. $\mathrm{Zn}$ ionomer was reported to have a single band at $1585 \mathrm{~cm}^{-1},{ }^{25}$ and $\mathrm{Zn}$-ionomer (ionomer based maleated EPM) had two peaks at around 1560 and $1630 \mathrm{~cm}^{-1}$, ${ }^{12}$ which originated from the $\mathrm{C}=\mathrm{O}$ stretching vibration of metal-carboxylate salts. The characteristic peaks of $\mathrm{Zn}$-ionomer at around 1563 and $1645 \mathrm{~cm}^{-1}$ were appeared in the I samples $\left(\mathrm{I}_{\mathrm{ZnO}(5)}, \mathrm{I}_{\mathrm{ZnO}(10)}, \mathrm{I}_{\mathrm{ZnSt} .(5)}, \mathrm{I}_{\mathrm{ZnSt.}(10)}\right.$, $\mathrm{I}_{\mathrm{ZnO}(5) / Z n S t .(5)}$ ), indicating the successful neutralization of CCAg-EPDM. On the other hand, the intensities of these two peaks from $\mathrm{I}_{\mathrm{ZnO}(5)}$ and $\mathrm{I}_{\mathrm{ZnO}(10)}$ were higher than those from $\mathrm{I}_{\mathrm{ZnSt} .(5)}$ and $\mathrm{I}_{\mathrm{ZnSt} .(10)}$. This was attributed to the higher $\mathrm{Zn}$ content of $\mathrm{I}_{\mathrm{ZnO}(5) /}$ $\mathrm{IZnO(10)}$ than $\mathrm{I}_{\mathrm{ZnSt.(5)}} / \mathrm{I}_{\mathrm{ZnSt} .(10)}$. The peak intensity was proportional to the $\mathrm{Zn}$ atom content of the I samples. $\mathrm{I}_{\mathrm{ZnSt} .(5)}$ and $\mathrm{I}_{\mathrm{ZnSt} .(10)}$ showed a characteristic peak for the stearate component at around $1539 \mathrm{~cm}^{-1} .{ }^{26}$ The $\mathrm{I}_{\mathrm{ZnO}(5) / Z n S t .(5)}$ ) sample had both two characteristic peaks for the $\mathrm{Zn}$-ionomer and stearate component.
Generally, the melt flow index of a polymer is related directly to the melt viscosity, which depends on the molecular weight, molecular weight distribution and structure (polar/ non-polar, branching/crosslinking). In particular, for practical applications, melt flow index is a critical factor determining the melt processibility and usability requirements of customers of thermoplastic polymers. The melt flow indexes of pristine ethylene propylene diene monomer, CCA-g-EPDM and various ionomers $\left(\mathrm{I}_{\mathrm{ZnO}(5)}, \mathrm{I}_{\mathrm{ZnO}(10)}, \mathrm{I}_{\mathrm{ZnSt} .(5)}, \mathrm{I}_{\mathrm{ZnSt} .(10)}, \mathrm{I}_{\mathrm{ZnO}(5)} / \mathrm{ZnSt.(5)}\right)$ containing $\mathrm{ZnO}$ or/and zinc stearate were 12, 10 and 5-9, respectively. The melt flow index increased in the order of $\mathrm{EPDM}>\mathrm{CCA}-\mathrm{g}-\mathrm{EPDM}>$ various ionomers $\left(\mathrm{I}_{\mathrm{ZnO}(5)}, \mathrm{I}_{\mathrm{ZnO}(10)}\right.$, $\mathrm{I}_{\mathrm{ZnSt} \text { (5), }} \mathrm{I}_{\mathrm{ZnSt.(10)}}$ and $\mathrm{I}_{\mathrm{ZnO}(5) / \mathrm{ZnSt} \text { (5) }}$ containing $\mathrm{ZnO}$ or/and zinc stearate). The melt flow index decreased in the following order: pristine EPDM $<$ CCA-g-EPDM $<\mathrm{I}_{\mathrm{ZnSt} .(10)}<\mathrm{I}_{\mathrm{ZnO}(5) / Z n S t .(5)}$ $<\mathrm{I}_{\mathrm{ZnSt} .(5)}<\mathrm{I}_{\mathrm{ZnO}(5)}<\mathrm{I}_{\mathrm{ZnO}(10)}$. The melt flow index of $\mathrm{I}_{\mathrm{ZnO}(5)} / \mathrm{I}_{\mathrm{ZnO}(10)}$ containing $\mathrm{ZnO}$ were lower than those of $\mathrm{I}_{\mathrm{ZnSt} .(5)}, \mathrm{I}_{\mathrm{ZnSt} .(10)}$. This might be due to the filler role of $\mathrm{ZnO}$.

The shore A hardness and specific gravity of CCA-gEPDM and the ionomers $\left(\mathrm{I}_{\mathrm{ZnO}(5)}, \mathrm{I}_{\mathrm{ZnO}(10)}, \mathrm{I}_{\mathrm{ZnSt} .(5)}, \mathrm{I}_{\mathrm{ZnSt} .(10)}, \mathrm{I}_{\mathrm{ZnO}(5) /}\right.$ ZnSt.(5)) were higher than those of pristine ethylene propylene diene monomer at room temperature. The higher hardness and specific gravity of CCA-g-EPDM and ionomers ( $\mathrm{I}_{\mathrm{ZnO}(5)}, \mathrm{I}_{\mathrm{ZnO}(10)}$, $\left.\mathrm{I}_{\mathrm{ZnSt} .(5)}, \mathrm{I}_{\mathrm{ZnSt} .(10)}, \mathrm{I}_{\mathrm{ZnO}(5) / \mathrm{ZnSt} .(5)}\right)$ might be due to hydrogen bonding/ Coulomb attractive forces of carboxylic acid groups/salt groups and the filler role of the metal compound.

Fig. 2 shows the stress-strain curves of the film samples. The tensile strength and modulus increased in the following order: $\mathrm{I}_{\mathrm{ZnO}(5) / Z n S t .(5)}>\mathrm{I}_{\mathrm{ZnO}(10)}>\mathrm{I}_{\mathrm{ZnO}(5)}>\mathrm{I}_{\mathrm{ZnSt} .(10)}>\mathrm{I}_{\mathrm{ZnSt} .(5)}>\mathrm{CCA}-\mathrm{g}-$ $\mathrm{EPDM}>$ pristine EPDM. This indicates marked increases in the tensile strength and modulus at $100 \%$ and $300 \%$ as a result of grafting and subsequent neutralization. The tear 
strength was also increased by grafting and neutralization. This might be due to the hydrogen bonding of carboxylic groups in CCA-g-EPDM and the Coulomb attractive forces of ionic groups (ionic cluster) in the ionomers $\left(\mathrm{I}_{\mathrm{ZnO}(5)}, \mathrm{I}_{\mathrm{ZnO}(10)}, \mathrm{I}_{\mathrm{ZnSt} .(5)}\right.$, $\mathrm{I}_{\mathrm{ZnSt} .(10)}$ and $\mathrm{I}_{\mathrm{ZnO}(5) / \mathrm{ZnSt} \text { (5) }}$ samples).

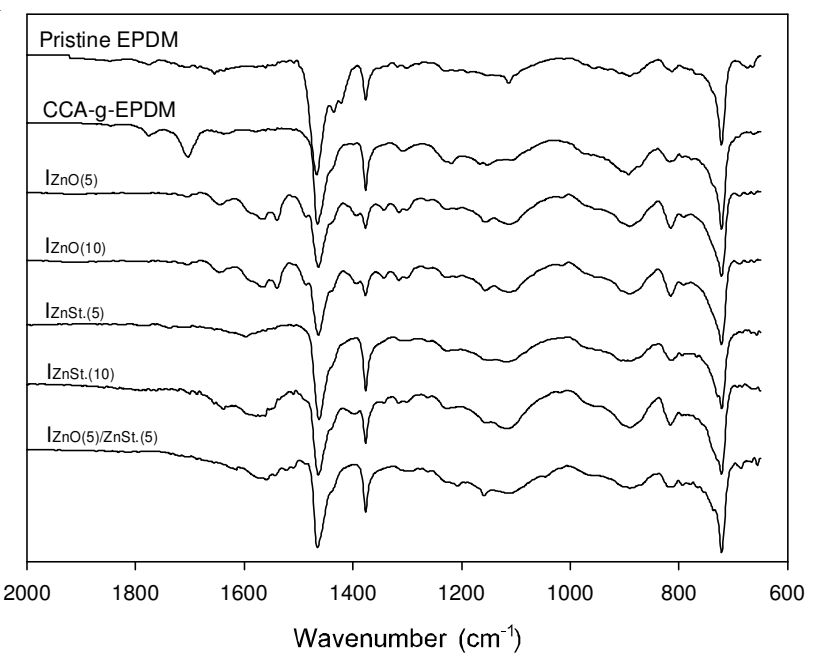

Fig. 1. FTIR spectra of pristine EPDM, CCA-g-EPDM, $\mathrm{I}_{\mathrm{ZnO}(5)}, \mathrm{I}_{\mathrm{ZnO}(10)}, \mathrm{I}_{\mathrm{ZnSt} .(5)}$, $\mathrm{I}_{\mathrm{ZnSt} .(10)}$ and $\mathrm{I}_{\mathrm{ZnO}(5) / \mathrm{ZnSt} .(5)}$

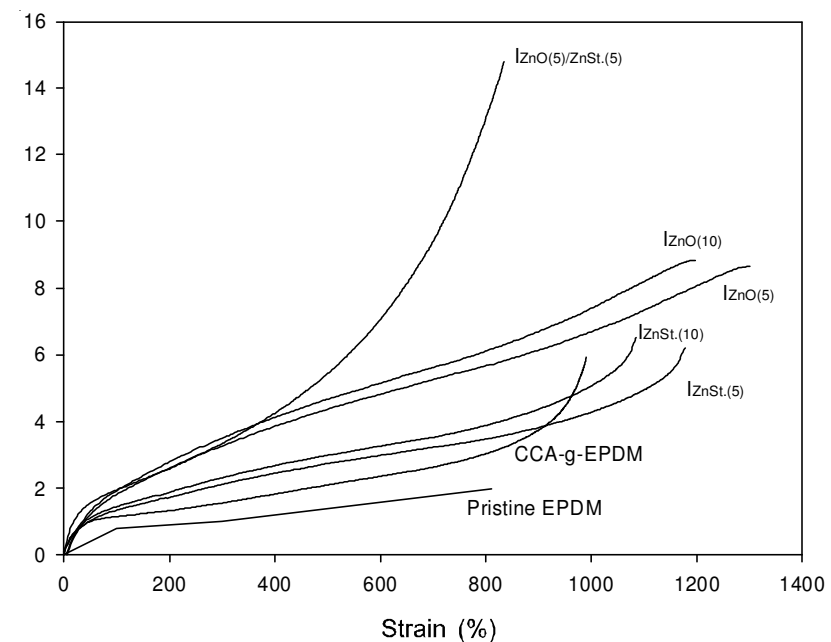

Fig. 2. Stress-Strain curves of pristine EPDM, CCA-g-EPDM, $\mathrm{I}_{\mathrm{ZnO}(5)}, \mathrm{I}_{\mathrm{ZnO}(10)}$, $\mathrm{I}_{\mathrm{ZnSt} .(5)}, \mathrm{I}_{\mathrm{ZnSt} .(10)}$ and $\mathrm{I}_{\mathrm{ZnO}(5) / \mathrm{ZnSt} .(5)}$

Generally, a compression set test measures the ability of rubber compounds to retain their elastic properties after prolonged compressive stress. The compression set is the end result of progressive stress relaxation, which is the steady decline in the sealing force when an elastomer is compressed over a long period of time. The compression elasticity is inversely proportional to the compression set \%. A lower compression set results in improved sealing and a longer service life. The compression set \% (90\%) of CCA-g-EPDM was similar to that $(89 \%)$ of pristine ethylene propylene diene monomer. On the other hand, the ionomer samples $\left(\mathrm{I}_{\mathrm{ZnO}(5)}, \mathrm{I}_{\mathrm{ZnO}(10)}, \mathrm{I}_{\mathrm{ZnSt} .(5)}\right.$, $\left.\mathrm{I}_{\mathrm{ZnSt} .(10)}, \mathrm{I}_{\mathrm{ZnO}(5) / Z n S t .(5)}\right)$ had a lower compression set \% (63-79\%) than pristine ethylene propylene diene monomer and CCA-gEPDM. This was attributed to the increase in phase separation between the ionic cluster and matrix.

Among the ionomer samples $\left(\mathrm{I}_{\mathrm{ZnO}(10)}, \mathrm{I}_{\mathrm{ZnSt} .(5)}, \mathrm{I}_{\mathrm{ZnSt} .(10)}, \mathrm{I}_{\mathrm{ZnO}(5) /}\right.$ $\mathrm{ZnSt.(5)})$ prepared in this study, $\mathrm{I}_{\mathrm{ZnO}(5) / \mathrm{ZnSt} \text {.(5) }}$ exhibited the highest tensile strength/tear strength/modulus/hardness, but the lowest compression set \% (63\%). Therefore, $\mathrm{I}_{\mathrm{ZnO}(5) / \mathrm{ZnSt} .(5)}$ was considered the best thermoplastic elastomer. On the other hand, the reason why $\mathrm{I}_{\mathrm{ZnO}(5) / Z n S t .(5)}$ showed the best mechanical properties is unclear. More detailed studies on the effect of neutralization agents on the structural changes in ionomers are needed.

The mechanical properties of recycled samples of $\mathrm{I}_{\mathrm{ZnO}(5) /}$ Znst.(5) are shown in Table-3. The hardness and specific gravity were unchanged with increasing run number of melt processing. The tear strength and modulus at $100 \%$ and $300 \%$ decreased slightly with increasing run number of melt processing. On the other hand, the tensile strength, elongation at break and compression set increased slightly with increasing run number of melt processing. Fig. 3 shows that the tensile strength and compression set of $\mathrm{I}_{\mathrm{ZnO}(5) / \mathrm{ZnSt} \text { (5) }}$ increased slightly with increasing run number of melt processing up to 4 , i.e. there is no significant change in the mechanical properties and compression set with successive recycling. This suggests that an ionomer based on citraconated ethylene propylene diene monomer $\left(\mathrm{I}_{\mathrm{ZnO}(5) / \mathrm{ZnSt} .(5)}\right)$ prepared in this study exhibits excellent mechanical properties and recyclability.

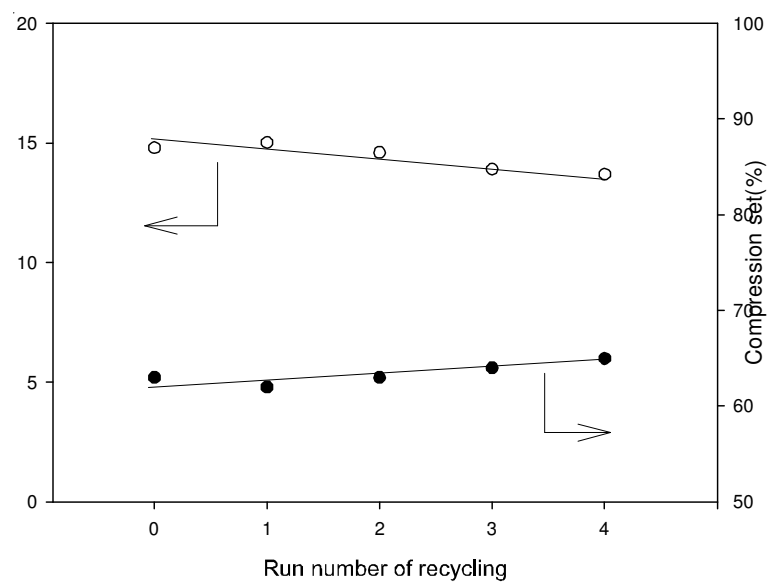

Fig. 3. Effect of the run number of recycling on the tensile strength and compression set of $\mathrm{I}_{\mathrm{ZnO}(5) / \mathrm{ZnSt} \text {.(5) }}$

TABLE-3

EFFECT OF THE RUN NUMBER OF RECYCLING ON THE PROPERTIES OF I $\mathrm{ZnO}_{\text {Zn(5)/ZnSt.(5). }}$

\begin{tabular}{|c|c|c|c|c|c|c|c|c|c|}
\hline \multirow[b]{2}{*}{$\begin{array}{c}\text { Run } \\
\text { number of } \\
\text { recycling }\end{array}$} & \multicolumn{9}{|c|}{ Properties } \\
\hline & $\begin{array}{c}\text { MFI } \\
\text { (g/10 min) }\end{array}$ & $\begin{array}{c}\text { Hardness } \\
\text { (Shore } \\
\text { A) }\end{array}$ & $\begin{array}{l}\text { Specific } \\
\text { gravity }\end{array}$ & $\begin{array}{l}\text { Tensile } \\
\text { strength } \\
\text { (Mpa) }\end{array}$ & $\begin{array}{l}\text { Elongation } \\
\text { at break }(\%)\end{array}$ & $\begin{array}{l}\text { Modulus } \\
\text { at } 100 \% \\
\text { (Mpa) }\end{array}$ & $\begin{array}{c}\text { Modulus } \\
\text { at } 300 \% \\
(\mathrm{Mpa})\end{array}$ & $\begin{array}{c}\text { Tear } \\
\text { strength } \\
\text { (kN.m) }\end{array}$ & $\begin{array}{c}\text { Compression } \\
\text { set }(\%)\end{array}$ \\
\hline 0 & 8 & $66-67$ & 0.92 & 14.80 & 835 & 1.96 & 3.33 & 43.1 & 63 \\
\hline 1 & 9 & $67-68$ & 0.92 & 15.02 & 850 & 1.99 & 3.20 & 42.1 & 62 \\
\hline 2 & 9 & $67-68$ & 0.92 & 14.60 & 870 & 1.89 & 3.15 & 41.8 & 63 \\
\hline 3 & 9 & $66-67$ & 0.92 & 13.90 & 885 & 1.83 & 3.12 & 41.5 & 64 \\
\hline 4 & 10 & $66-67$ & 0.92 & 13.70 & 910 & 1.80 & 3.11 & 41.5 & 65 \\
\hline
\end{tabular}




\section{Conclusion}

Citraconated ethylene propylene diene monomer (CCAg-EPDM) was synthesized by melt grafting from citraconic acid (CCA)/EPDM/free radical initiator [2,5-dimethyl-2,5di(tert-butyl peroxy) hexane: L-101]. To produce a high performance thermo-reversible ionic crosslinked elastomer, ionomers $\left(\mathrm{I}_{\mathrm{ZnO}(5)}, \mathrm{I}_{\mathrm{ZnO}(10)}, \mathrm{I}_{\mathrm{ZnSt} .(5)}, \mathrm{I}_{\mathrm{ZnSt.}(10)}, \mathrm{I}_{\mathrm{ZnO}(5) / \mathrm{ZnSt} .(5)}\right)$ based on citraconated ethylene propylene diene monomer were prepared by melt mixing from CCA-g-EPDM and zinc oxide and/or zinc stearate using a Haake Rheocorder. This study compared the mechanical properties of pristine ethylene propylene diene monomer, CCA-g-EPDM and $\mathrm{I}_{\mathrm{ZnO}(5)}, \mathrm{I}_{\mathrm{ZnO}(10)}, \mathrm{I}_{\mathrm{ZnSt} .(5)}, \mathrm{I}_{\mathrm{ZnSt} .(10)}$,

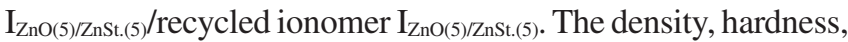
tensile strength, elongation at break, modulus and tear strength increased in the order, ionomers $>$ CCA-g-EPDM $>$ pristine ethylene propylene diene monomer, whereas the compression set showed the opposite order. This suggests that the mechanical properties were increased by grafting and subsequent neutralization. The compression set \% (90\%) of CCA-g-EPDM was similar to that of pristine ethylene propylene diene monomer $(89 \%)$. On the other hand, the ionomer samples $\left(\mathrm{I}_{\mathrm{ZnO}(5)}, \mathrm{I}_{\mathrm{ZnO}(10)}\right.$, $\left.\mathrm{I}_{\mathrm{ZnSt} .(5)}, \mathrm{I}_{\mathrm{ZnSt} .(10)}, \mathrm{I}_{\mathrm{ZnO}(5) / \mathrm{ZnSt} .(5)}\right)$ have a lower compression set \% (63-79\%) than pristine ethylene propylene diene monomer and CCA-g-EPDM. Among the ionomer samples ( $\mathrm{I}_{\mathrm{ZnO}(10)}$, $\left.\mathrm{I}_{\mathrm{ZnSt} .(5)}, \mathrm{I}_{\mathrm{ZnSt} .(10)}, \mathrm{I}_{\mathrm{ZnO}(5) / \mathrm{ZnSt} .(5)}\right), \mathrm{I}_{\mathrm{ZnO}(5) / Z n S t .(5)}$ exhibited the highest tensile strength/tear strength/modulus/hardness, but had the lowest compression set \% (63\%). This suggests that $\mathrm{I}_{\mathrm{ZnO}(5) /}$ ZnSt.(5) shows the highest performance ionic thermoplastic rubber. The mechanical properties and compression set of $\mathrm{I}_{\mathrm{ZnO}(5) / \mathrm{ZnSt} \text { (5) }}$ increased slightly with successive recycling. This suggests that the recyclable ionomers based on citraconated ethylene propylene diene monomer prepared in this study have potential as new high performance thermoplastic elastomers.

\section{ACKNOWLEDGEMENTS}

This study was supported by the Fundamental R \& D Program for Core Technology of Materials funded by the Ministry of Knowledge Economy, Republic of Korea (Project Number 10037160).

\section{REFERENCES}

1. W. Hoffmann, Rubber Technology Handbook, Hanser Gardner Publications, Munich (2000)

2. R.A. Weiss, J.A. Fitzerald and D. Kim, Macromolecules, 24, 1071 (1991).

3. C.G. Bazium and A. Eisenberg, J. Chem. Educ., 58, 938 (1981).

4. W.J. MacKnight and T.R. Earnest, J. Polym. Sci., Macromol. Rev., 16, 41 (1981).

5. A. Eisenberg and J.S. Kim, Introduction to Ionomers, John Wiley \& Sons Inc., New York (1998)

6. L. Holliday, Ionic Polymers, Ed., Applied Science Publishers, London (1975).

7. A. Eisenberg, Ions in Polymers, American Chemical Society, Washington, DC (1980).

8. M.R.Tant, in eds.: K.A. Mauritz and G.L.Wikes, Ionomers: Synthesis, Structure, Properties and Application, Champman \& Hall, London (1997).

9. G. Holden, N.R. Legge and R.P. Quirk, Thermoplastic Elastomers: A Comprehensive Review, Hanser, Munich (1987).

10. P. Antony and S.K. De, J. Macromol. Sci. Polym. Rev., C41, 41 (2001).

11. S. Bagrodia, G.L. Wilkes and J.P. Kennedy, Polym. Eng. Sci., 26, 662 (1986).

12. M.A.J. Van Der Mee, J.G.P. Goossens and M.Van Duin, Rubber Chem. Technol., 81, 96 (2009).

13. M. Pineri and C. Meyer, J. Polym. Sci.: Polym. Phys. Ed., 12, 115 (1974).

14. A.U. Paeglis and F.X. O'Shea, Rubber Chem. Technol., 61, 223 (1986).

15. N. Lopattananon, A. Kraibut, R. Sangjan and M. Seadan, J. Appl. Polym. Sci., 105, 1444 (2007).

16. R. Jerome, J. Horrion, R. Fayt and Ph. Tayssie, Macromolecules, 17, 2447 (1984).

17. U.K. Mondal, D.K. Tripathy and S.K. De, Polymer, 34, 3831 (1993).

18. K. Sato, Rubber Chem. Technol., 56, 1942 (1984).

19. P.K. Agarwal and R.D. Lundberg, Macromolecules, 17, 1918 (1984).

20. A.U. Paeglis and F.X. Oshea, Rubber Chem. Technol., 60, 223 (1988).

21. A.J. Oostenbrink and R.J. Gaymans, Polymer, 33, 3086 (1992).

22. D.R. Paul and J.W. Barlow, Polymer, 33, 268 (1992).

23. R. Greco, M. Malineonico, E. Martuscelli, G. Rogosta and G. Scaizi, Polymer, 28, 1185 (1987).

24. E.N. Kresge, Ionic Bonding in Elastomeric Networks, 18th Canadian High Polymer Forum, Hamilton, Ontario, Canada (1987).

25. B.A. Brozoski, M.M. Colemam and P.C. Painter, Macromolecules, 17, 230 (1984)

26. G. Guo, C. Shi, D. Tao, W. Qian and D. Han, J. Alloys Compd., 472, 343 (2009). 